\title{
10
}

\section{The Ryukyu Islands and the Northern Frontier of Prehistoric Austronesian Settlement}

\author{
Mark J. Hudson
}

The origins and dispersals of Austronesian peoples have been widely discussed in Pacific archaeology. There is broad agreement that Taiwan was the primary source for the initial expansion of these human populations in the second half of the third millennium BC. From Taiwan, these Neolithic populations migrated into the Philippines, and then to Indonesia and the Marianas. Rice and pottery disappeared as Austronesians moved further into the Pacific, but agriculture, long-distance voyaging, and an ideology of exploration were widely shared hallmarks of the migration and colonisation.

While numerous studies have examined the movement of Austronesian-speaking peoples from Taiwan to the south and east, little attention has so far been given to expansions to the Ryukyu Islands, situated 110-320 km northeast of Taiwan. This paper argues that the southern Ryukyu Islands should be included within the Austronesian cultural sphere from the fourth millennium BP until the beginning of the second millennium AD. The prehistory of the southern Ryukyus is important to Austronesian studies because their proximity to Taiwan can help test models of Austronesian origins and early expansions. The southern Ryukyus form part of the northern frontier of settlement in the North Pacific, a frontier that followed a remarkably uniform line between latitudes $23-27^{\circ} \mathrm{N}$. In the Ryukyus this frontier was maintained despite the existence of further habitable islands only $250 \mathrm{~km}$ to the north.

\section{Introduction}

The archaeology of the Pacific Ocean in the late Holocene can be divided into two strikingly different cultural zones. Predominantly agricultural populations speaking languages derived from a common ancestor and displaying numerous commonalities in social and cultural traditions colonised the North Pacific, as far as Hawai'i and the Marianas as well as much of the South Pacific. In contrast, the North Pacific coasts and islands above Hawai $i$ and the Marianas were populated by diverse cultures and languages possessed by peoples who were almost exclusively hunter-gatherers. The border between these two zones traversed a remarkably consistent line of latitude between 23 and $27^{\circ} \mathrm{N}$. This paper will examine this frontier in more detail and will discuss the position of the southern Ryukyu Islands in Austronesian prehistory. 


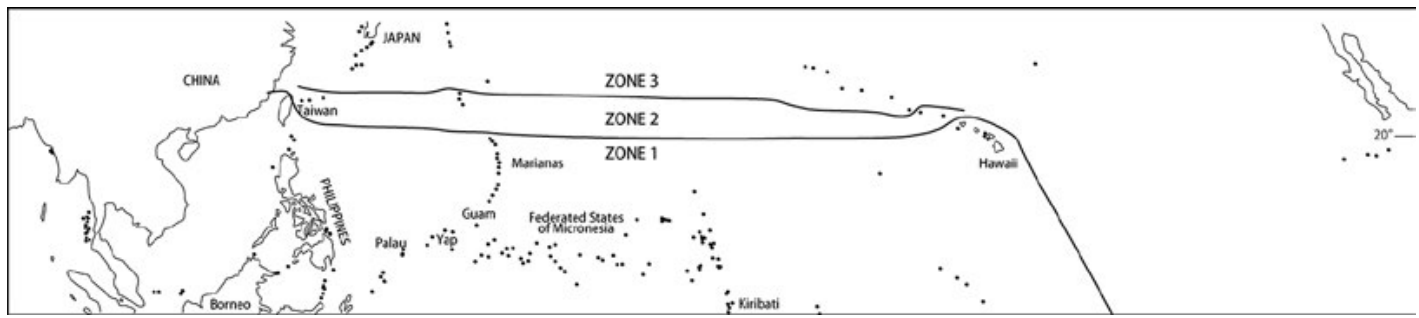

Figure 10.1 Austronesian settlement zones in the North Pacific.

Source: Drawn by J. Uchiyama using Peter Bellwood/ANU Cartography base map.

\section{Austronesian frontiers and the north Pacific}

In writing about the historical geography of borders, it is useful to distinguish between 'boundaries' that take the form of a line and 'frontiers' that comprise a broader zone (Batten 2003). The three archipelagoes that form the northern geographic limit of Austronesian colonisation are Hawai' $i$, the Marianas/Ogasawaras, and - I argue here - the Ryukyus, between latitudes 23 and $27^{\circ} \mathrm{N}$. These archipelagoes form a frontier in that, in all three cases, there was an area of permanent Austronesian settlement (Zone 1), a zone of once inhabited but later abandoned 'mystery islands' (Bellwood 1978; Zone 2), and a line beyond which Austronesians seem to have never settled (Zone 3; Figure 10.1). For example, in Hawai $i$, the large, agriculturally productive island of Kaua 'i (nicknamed the 'Garden Isle') marked the northern extent of Zone 1 at $22^{\circ} 13^{\prime} \mathrm{N}$. To the northwest, Zone 2 comprised the rocky islets of Nihoa and Necker, which have numerous archaeological sites, including ritual platforms (Emory 1928). These islands were, however, uninhabited when first visited by Europeans and may not have been permanently settled for long periods (Kirch 1985). Beyond Necker at $23^{\circ} 34^{\prime} \mathrm{N}$ stretches a series of small islands and atolls as far as Kure Atoll at $28^{\circ} 25^{\prime} \mathrm{N}$ that could potentially have been colonised, but there is no archaeological evidence that these Zone 3 islands were visited in prehistory (Rauzon 2001). In the Marianas, Zone 1 included almost all the islands of the Northern Marianas, except perhaps the small, barren Farallon de Medinilla north of Saipan and the active volcanic island of Uracas at $20^{\circ} \mathrm{N}$, in the far north of the archipelago (Russell 1998). According to a 1673 Jesuit report, Uracas was periodically visited to hunt sea birds, which were salted and distributed down the Northern Marianas chain (Coomans 1997). North of Uracas there is an almost $600 \mathrm{~km}$ wide stretch of ocean before the next island of Minami Iwo Jima is reached. Evidence for Zone 2 here comprises a number of finds of stone adzes and shell artefacts on landmasses in the Ogasawara (Bonin) Islands. These islands were all uninhabited when the Japanese reported on them in the seventeenth century (Oda 1981, 1990). Only one archaeological site on one of these islands, Ishino on Kita Iwo Jima ( $\left.25^{\circ} 26^{\prime} \mathrm{N}\right)$, has been excavated (Tokyo Board of Education 2005). The excavation produced two large stone concentrations with 163 earthenware sherds, 22 chipped stone axes, a small (3.3 cm long) Tridacna adze and two Tridacna adze blanks. An incised drawing was found on a rock in the northern stone concentration. The stone concentrations were covered by thick vegetation but not buried in the soil. A single ${ }^{14} \mathrm{C}$ date on carbonised material attached to a potsherd from a test excavation between the two stone concentrations produced a result of 2855 cal. BP (IAAA-41487). In the Ogasawaras, the northern limit of Zone 2 would seem to have been Chichijima (Peel Island) at $27^{\circ} 4^{\prime} \mathrm{N}$. Further north, the Izu chain as far south as Hachijo Island $\left(33^{\circ} 6^{\prime} \mathrm{N}\right)$ was part of the Jōmon cultural zone (Oda 1981, 1990). The southern Ryukus would appear to have had intermittent occupation in prehistory and can be considered a Zone 2-type Austronesian colonisation. 


\section{The archaeology of the southern Ryukyus}

The Ryukyu Islands were incorporated as Japanese territory in 1879 and are now split administratively between Kagoshima and Okinawa Prefectures. The islands in Okinawa Prefecture are usually divided into three cultural zones: the Amami Islands in the north near Kyushu, the Okinawa Islands in the centre, and the Sakishima Islands to the south closest to Taiwan (Figure 10.2). In the north, the Amami and Okinawa Islands as far south as Okinawa Main Island were settled by at least $6000 \mathrm{BP}$ by Jōmon populations originating on Kyushu Island (Takemoto 2003; Pearson 2013; Takamiya et al. 2016). To the south, the Sakishima Islands were inhabited by quite different cultures that will be discussed in more detail below. Although archaeological research in the southern Ryukyus began as early as 1904 and at least 77 prehistoric sites are now known in these islands (Shimabukuro 2011), many aspects of the archaeology of the southern Ryukyus remain poorly understood. Nevertheless, two Holocene-era prehistoric cultural phases are currently recognised in the southern Ryukyus (Ōhama 1999; Shimabukuro 2011; Pearson 2013). The earliest known Neolithic sites date to $c a .4200$ BP (or several centuries earlier) and are only found south of Miyako Island (Summerhayes and Anderson 2009). The initial Neolithic colonists of the southern Ryukyu Islands produced low-fired pottery known as the Shimotabaru type. The succeeding Late Neolithic began around 2800 BP. This phase lacks pottery and is characterised by Tridacna shell adzes. Many archaeologists have assumed that the early and late Neolithic phases of activity reflect colonisation of the islands by two different human populations, and that there was a hiatus between the two phases of occupation between 3500-2800 BP. So far, no archaeological sites that can be clearly dated to this hiatus period have been identified, implying that it might reflect real island abandonment and recolonisation. In the eleventh to twelfth centuries $\mathrm{AD}$, the Gusuku Culture spread down the Ryukyu chain from Japan, bringing agriculture, the contemporary Ryukyuan languages and new cultural items such as iron and Chinese ceramics (Hudson 1994; Miyagi 2012; Pearson 2013; Pellard 2015; Takamiya 2004; Yamamoto 2008). On Miyako there is no archaeological evidence for interaction between Late Neolithic and incoming Gusuku populations. However, a few sites on Ishigaki, Taketomi and Hateruma islands have produced Gusuku period ceramics from the upper layers of Late Neolithic sites (Kin 1994), suggesting some overlap and interaction between pre-existing cultural groups and the Gusuku colonists.

\section{The origins of Neolithic culture in the southern Ryukyus}

The Neolithic cultures of the southern Ryukyus have four possible origins. In order of geographical proximity, these are: (1) Taiwan, (2) the Ryukyu Jōmon cultures of Okinawa, (3) mainland China, and (4) the Philippines. Of these four, there is no archaeological evidence for (2) or (3). No sites in the southern Ryukyus have produced Jōmon-type remains and no Shimotabaru pottery, shell adzes or other features of southern Ryukyus prehistory have been found further north, beyond the Sakishima Islands. This clear division between the archaeological cultures of the central and southern Ryukyus would seem to rule out a Jōmon origin for the latter. The southern Ryukyus are approximately $500 \mathrm{~km}$ from the Chinese coast where the Neolithic and later cultures of Zhejiang and Fujian provinces have been extensively studied. However, the only archaeological finds from the southern Ryukyus that could possibly be linked with China are a number of Tang dynasty (AD 618-906) coins from Late Neolithic deposits. Such coins were widely distributed across East Asia and did not necessarily come directly from China. 


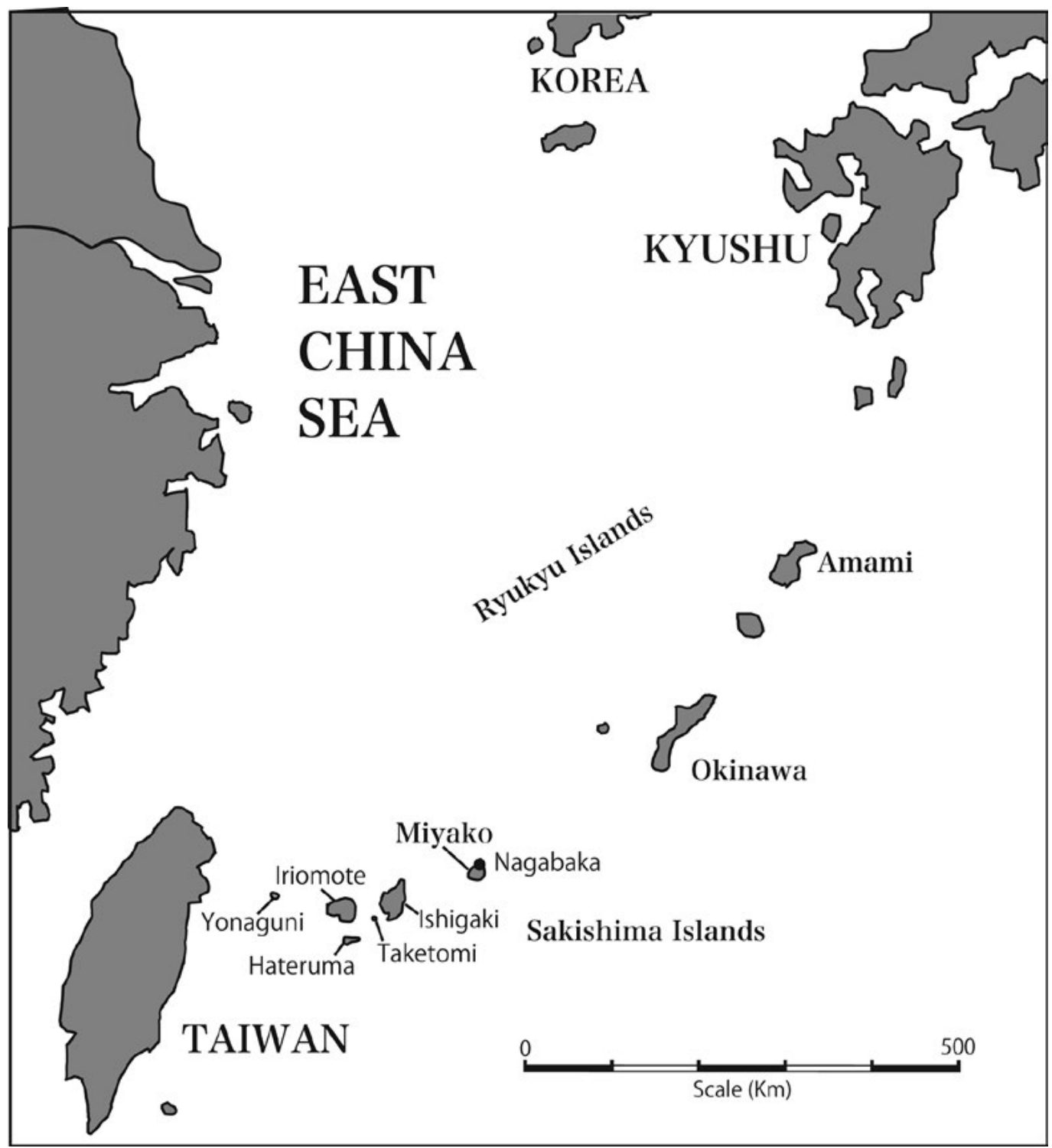

Figure 10.2 Map of the Ryukyu Islands showing the location of the Nagabaka site, Miyako Island. Source: M. Hudson.

Several archaeologists have proposed the Philippines as a possible source for the southern Ryukyu Neolithic, based on morphological similarities of shell adzes (Pearson 1969; Asato 1991). Shell adzes from the Philippines, however, are much older and fewer in number than in the Ryukyus. Almost 300 shell adzes are known from 43 sites the southern Ryukyus (Anzai 2009). In the Philippines, shell adzes have only been discovered at a 'few sites', including Duyong, Leta-leta, Balobok and Kamuanan (Ronquillo 1998: 63). Pawlik et al. (2015) have recently published a careful study of the problems of dating shell adzes in the Philippines. However, their analysis of the shell adze from the Bubog I site confirms that such adzes were present in the Philippines by the early Middle Holocene. Early dates and the 'scarcity' (Ronquillo 1998: 63) of shell adzes in the Philippines do not necessarily rule out connections with the Ryukyus, and Pawlik et al. (2015) follow several earlier scholars in arguing that shell adzes spread through discrete interregional contact between Island Southeast Asia, the Moluccas and Island Melanesia. However, the absence of other material culture parallels and the great distance involved suggest prehistoric links between the Philippines and the southern Ryukyus are unlikely. 


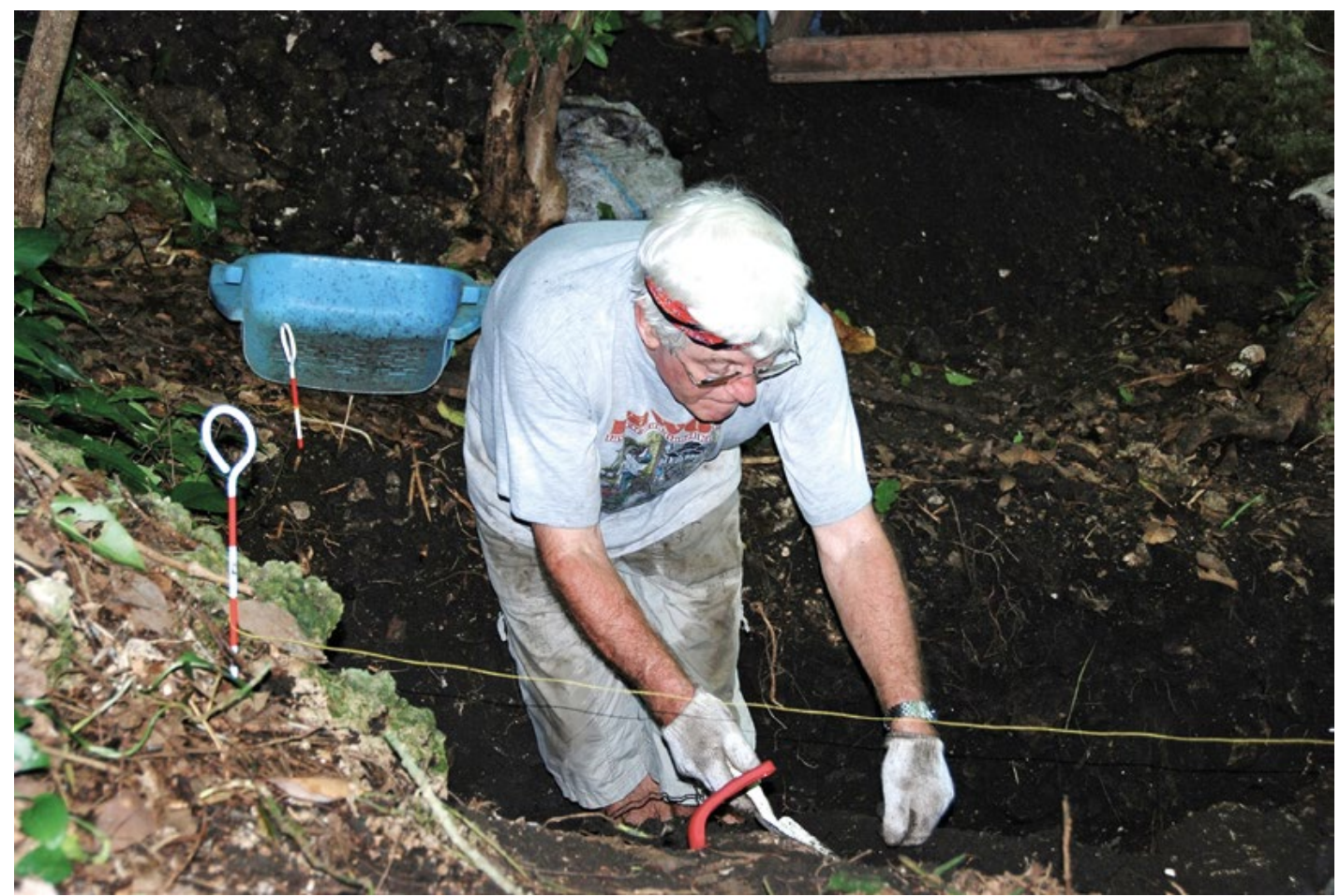

Figure 10.3 Peter Bellwood excavating at the Nagabaka site in 2008.

Source: M. Hudson.

Taiwan is geographically the closest potential source area, lying only $c a .110 \mathrm{~km}$ from Yonaguni Island. Despite this proximity, the prehistoric cultures of Taiwan and the southern Ryukyus were rather different in many respects (Hung and Carson 2014). The main aspects of material culture that suggest connections between the two areas that have been proposed are pottery and stone adzes (Pearson 1969). Early Neolithic Shimotabaru type pottery from the southern Ryukyus is a low-fired earthenware with flat-bottomed vessels, sometimes with lug handles, and made using local clays (Summerhayes and Anderson 2009). Shimotabaru pottery lacks most of the vessel forms and decorative designs found in Neolithic ceramics from Taiwan. However, flat-bottom vessels with lug handles are known from Middle Neolithic (4500-3500 BP) sites on Taiwan such as Yanliao and Huagangshan (Summerhayes and Anderson 2009; Lu 2012). Decoration involving lines of circular perforations is also found at both Huagangshan and in Shimotabaru wares (Lu 2012). Many scholars including Pearson (1969) and Summerhayes and Anderson (2009) have discussed the similarities in morphology of stone axes and adzes from Taiwan and the southern Ryukyus. Lu (2012) has recently emphasised similarities in style but differences in technique, especially the absence of 'saw-polishing' in the Ryukyus. Shimotabaru pottery and stone adzes from the southern Ryukyus seem to have been locally made 'poor imitations' of those found in Taiwan (Summerhayes and Anderson 2009: 87). Nevertheless the most parsimonious explanation for the origins of the peoples that arrived in the southern Ryukyus at the end of the third millennium BC is from Taiwan.

Recent finds of slate artefacts from the site of Nagabaka on Miyako Island may provide further evidence of a link with Taiwan. Nagabaka is a rock shelter and shell midden excavated by the author since 2006 (Figure 10.3). The site dates from around 4200 BP to at least the tenth century AD (Nagabaka Archaeological Project 2013). Excavations inside the rock shelter in 2013 produced two slate artefacts. Morphologically, these artefacts are similar to sickles and reaping knives known in Neolithic Taiwan. The 'sickle' is a $44 \mathrm{~mm}$ long distal fragment from a 
longer blade with a maximum width and thickness of 17 and $2 \mathrm{~mm}$, respectively (Figure 10.4). The 'reaping knife' is $61 \mathrm{~mm}$ long, $36 \mathrm{~mm}$ wide and $6 \mathrm{~mm}$ thick and appears similar to the knife from Tapenkeng, Taiwan illustrated in Chang (1967: Plate 92, P; Figure 10.5). Although there is a slate source on Ishigaki Island, no other slate artefacts have been identified in the southern Ryukyus. Slate from Okinawa Island was used to make artefacts in the central Ryukyus, but the absence of contacts between the southern and central Ryukyus in prehistory suggests a source in Taiwan is possible for the two artefacts in Nagabaka. This possibility of a Taiwan source requires further research and analysis.

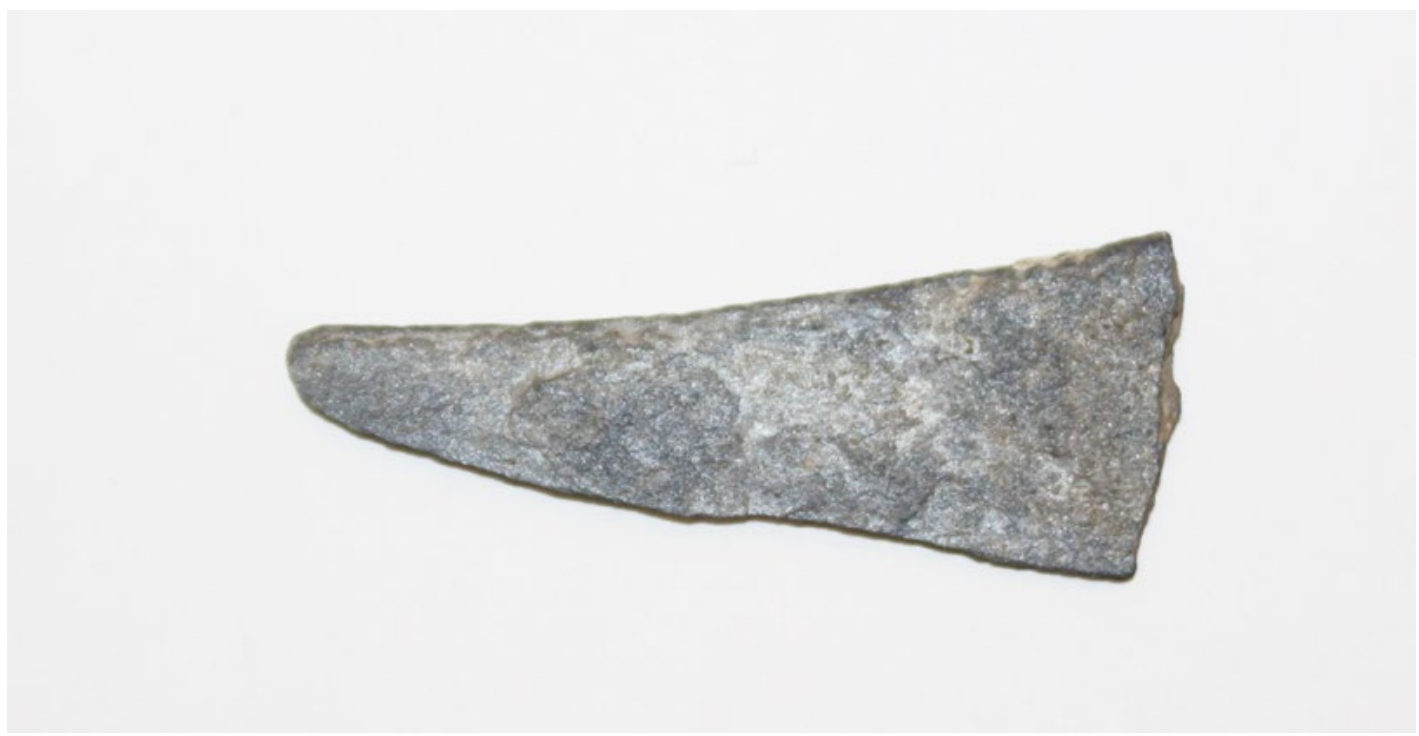

Figure 10.4 Slate sickle from Nagabaka.

Source: M. Hudson.

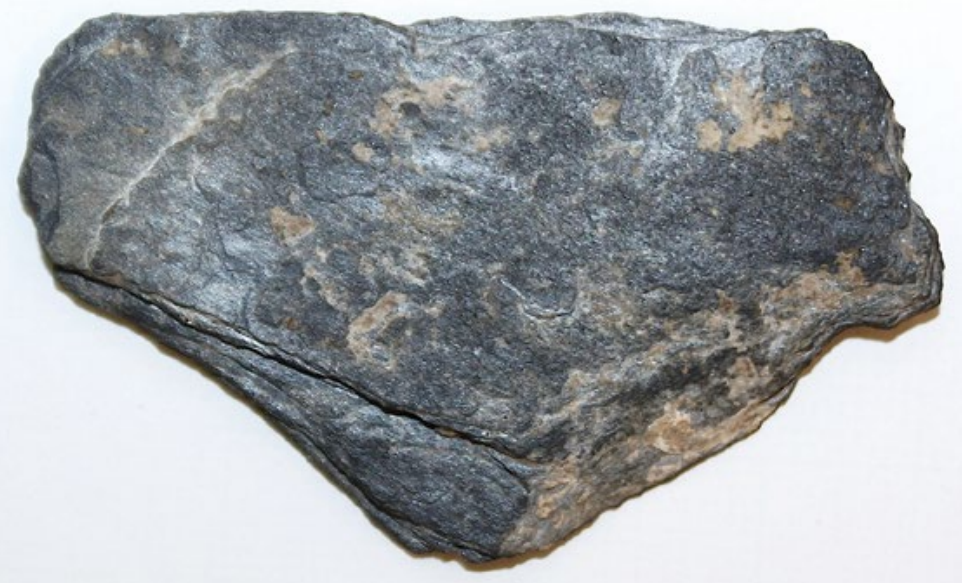

Figure 10.5 Slate reaping knife from Nagabaka.

Source: M. Hudson. 


\section{Austronesians and the southern Ryukyus}

If Okinawa and China can be ruled out as sources for the prehistoric cultures of the southern Ryukyus, then an origin to the south is almost certain. While Taiwan seems the most probable source, other possibilities such as the Philippines or even Micronesia were all areas where Austronesian languages were the dominant or only language spoken at this time. It thus seems extremely likely that the southern Ryukyus were also home to Austronesian languages in the Neolithic. There is no historical or linguistic evidence that Austronesian languages were ever spoken in the southern Ryukyus (Pellard 2015). The historic languages of these islands are part of the Ryukyuan branch of Japonic, which spread down the Ryukyu chain from Japan in the medieval period (tenth to twelfth centuries $A D$ ) in association with the spread of farming, a process that presumably involved the replacement of earlier languages in the islands (Hudson 1994, 1999; Pellard 2015). Evidence from biological anthropology supports this medieval immigration into the Ryukyus (Pietrusewsky 2010) and the southern Ryukyus would appear to be an unusual example of Austronesian languages being replaced by a later farming/language dispersal.

Another possibility, suggested to me by Peter Bellwood himself, is that the Neolithic people of the southern Ryukyus were speakers of a pre-Austronesian language who were pushed out of Taiwan by expanding Austronesians. Based on evidence from Qing period historical records and from Aboriginal folklore, it is sometimes suggested that pre-Austronesians in Taiwan were a so-called 'Negrito' people (e.g. Chai 1968). This pre-Austronesian theory certainly warrants further consideration since, as discussed below, the Neolithic cultures of the southern Ryukyus display some striking differences from other prehistoric Austronesian cultures in Southeast Asia and the Pacific.

Despite its proximity to Taiwan and probable origins on that island, the Neolithic of the southern Ryukyus is quite different from the Neolithic cultures of Taiwan, the Batanes Islands and other regions of the Philippines, which are usually linked with early Austronesian expansions. Archaeological components of these expansions included rice cultivation, domesticated pigs and dogs, red-slipped pottery, earthenware spindle whorls, stone adzes, Taiwan slate and nephrite, notched pebble sinkers, stone bark cloth beaters, fishhooks and a variety of shell artefacts (Bellwood 2011: S369). Of these, only the dog and 'poor imitations' (see above) of Taiwanese pottery and stone adzes have been found in the southern Ryukyus, although the two slate artefacts from Nagabaka mentioned above may be another possible link. While agricultural expansion is the most widely favoured explanation for the spread of the Austronesians, the prehistoric sites of the southern Ryukyus offer no evidence of cultivated plants and all known sites appear to have had a foraging economy. Water flotation has been conducted at the Arafu site on Miyako as well as at Nagabaka, but has produced no evidence for rice or other cultigens (Takamiya 2003). The use of root crops such as taro is a possibility but there is no direct evidence from the prehistoric period yet (Matthews et al. 1992). Pigs were common and were certainly transported to smaller islands such as Hateruma, but there is no evidence for domestication. The chicken is not found in the southern Ryukyus until the medieval era. An isotope analysis of the Late Neolithic human femur from Amitori produced results consistent with evidence for heavy reliance on reef fish and shellfish (Hōjō and Yoshida 2007).

Fishing adaptations in the southern Ryukyus were also very different from those reconstructed for Taiwan, the Batanes and the Marianas, where offshore species such as dolphinfish and marlin were commonly taken (Hung et al. 2011: 921). Inshore parrotfish comprised 80 per cent (on MNIs) of the Nagabaka sample (Najima 2013), but only reached 3 per cent (on weight) at Eluanbi II in southern Taiwan (Li 2001). In contrast to Taiwan, the Philippines, and most of Oceania, no fishhooks are known from the Neolithic of the southern Ryukyus. 
These significant differences in subsistence do not necessarily contradict the basic model of farming dispersals for the early Austronesian expansion. Growing Neolithic population densities on Taiwan encouraged groups to fission off in search of new land and opportunities. While the net result was the spread of agriculture, when geographical conditions were not appropriate for farming or where other, abundant resources were available it can be presumed that the groups concerned would have forfeited agriculture in favour of other resources (cf. Anderson 1996). One problem here, of course, is how the southern Ryukyu people apparently managed to maintain a 'strandlooper' (Groube 1971) subsistence strategy for thousands of years while elsewhere in the Pacific population growth led quickly to the re-adoption of agriculture. The high productivity of the coral reef foraging adaptation in the prehistoric Ryukyus was potentially a key factor here (Takamiya et al. 2016).

The archaeological record from the southern Ryukyus provides no support for alternative views of Austronesian expansions as part of maritime trade networks (cf. Bulbeck 2008; Goodenough 1996; Oppenheimer and Richards 2002; Solheim 1975, 2007). The Ryukyus are, in fact, a good place to test such ideas about the role of maritime trade networks since they are geographically close to the states and trading centres of East and Southeast Asia. By the Late Neolithic period in the southern Ryukyus, Southeast Asia had already been incorporated into trading networks that linked China, India, and even West Asia. The southern Ryukyus, however, have produced only a handful of iron objects and Tang coins - all from Late Neolithic deposits - that could conceivably be linked with such trade. The archaeology of the southern Ryukyus islands provides no evidence to support the hypothesis that maritime trading networks were a major motivating factor behind the dispersal of Austronesian peoples. In contrast, extreme cultural isolation seems to be a defining feature of the southern Ryukyu Neolithic.

\section{The northern frontier of the Austronesian world}

If, as argued above, a case can be made that the southern Ryukyus were part of the northern frontier of the Austronesian world, what if any common factors can be discerned between the Ryukyus, the Marianas and Hawai'i? If the southern Ryukyus were a 'Zone 2' area of settlement, then they differ from the northwestern Hawaiian and Ogasawara Islands in forming home to a zone of apparently stable prehistoric settlement that continued for at least 2,000 years. Here the northern limit of Zone 2 was northern Miyako ( $\left.24^{0} 56^{\prime} \mathrm{N}\right)$. Previous studies on the Pacific 'mystery islands' have identified island size, cultural isolation, low ecological diversity and low rainfall as factors leading to island abandonment in Polynesia (Anderson 2001, 2002). These factors seem to apply to Hawai' $i$ and the Ogasawaras. In Hawai ' $i$, a stormy passage between Kaua'i and Nihoa limited voyaging in that direction and the northwestern Hawaiian Islands are extremely small, isolated, and generally unsuitable for permanent settlement (Rauzon 2001). In the Ogasawaras, the $600 \mathrm{~km}$ sea gap between these islands and the northern Marianas was probably a major factor limiting exploration and settlement to the north. If Hawai' $i$ and the Ogasawaras thus seem to fit the causal factors previously suggested for island abandonment in Polynesia, the Ryukyus are clearly a separate case. The apparent failure of Austronesians to expand north beyond Miyako cannot be explained by geographical isolation, island size or ecological diversity. The next island from Miyako, Okinawa Island, is only $250 \mathrm{~km}$ distant, has a surface area of over $1,200 \mathrm{~km}^{2}$ and a similar natural environment to the southern Ryukyus. Prehistoric populations on both sides of this ocean gap possessed remarkably similar subsistence adaptations, yet both groups seem to have remained in their respective cultural worlds, eschewing the exploration and interaction that was so common elsewhere in the Pacific. 


\section{References}

Anderson, A.J. 1996. Adaptive voyaging and subsistence strategies in the early settlement of East Polynesia. In T. Akazawa and E.J.E. Szathmáry (eds), Prehistoric Mongoloid Dispersals, pp. 359-373. Oxford: Oxford University Press.

- 2001. No meat on that beautiful shore: The prehistoric abandonment of subtropical Polynesian islands. International Journal of Osteoarchaeology 11: 14-23. doi.org/10.1002/oa.542.

- 2002. Faunal collapse, landscape change and settlement history in Remote Oceania. World Archaeology 33: 375-390. doi.org/10.1080/00438240120107431.

Anzai, E. 2009. Sakishima shotō shutsudo no shakogai-sei kaifu ni tsuite [The Tridacna adzes excavated from the Sakishima islands]. In Ishigaki City (eds), Ishigaki shishi köko visual-ban [A visual history and archaeology of Ishigaki City], vol. 3, pp. 61-64. Ishigaki: Ishigaki City.

Asato, S. 1991. The distribution of Tridacna shell adzes in the southern Ryukyu islands. Bulletin of the Indo-Pacific Prehistory Association 10: 282-291. doi.org/10.7152/bippa.v10i0.11319.

Batten, B.L. 2003. To the Ends of Japan: Premodern Frontiers, Boundaries, and Interactions. Honolulu: University of Hawai i Press.

Bellwood, P. 1978. Man's Conquest of the Pacific. London: Collins.

- 2011. Holocene population history in the Pacific region as a model for worldwide food producer dispersals. Current Anthropology 52: S363-378. doi.org/10.1086/658181.

Bulbeck, D. 2008. An integrated perspective on the Austronesian diaspora: The switch from cereal agriculture to maritime foraging in the colonization of Island Southeast Asia. Australian Archaeology 67: 31-51. doi.org/10.1080/03122417.2008.11681877.

Chai, C.-K. 1968. Taiwan Aborigines: A Genetic Study of Tribal Variations. Cambridge, MA: Harvard University Press; and Taipei: Bookcase Shop.

Chang, K.-C. 1967. Fengpitou, Tapenkeng, and the Prehistory of Taiwan. New Haven: Department of Anthropology, Yale University.

Coomans, P. 1997. History of the Mission in the Mariana Islands, 1667-1673. Occasional Historical Papers no. 4. Saipan: Division of Historic Preservation.

Emory, K.P. 1928. Archaeology of Nihoa and Necker islands. Honolulu: Bishop Museum Bulletin 53.

Goodenough, W.H. 1996. Introduction. In W.H. Goodenough (ed.), Prehistoric Settlement of the Pacific, pp. 1-10. Philadelphia: American Philosophical Society. doi.org/10.2307/1006617.

Groube, L. 1971. Tonga, Lapita pottery, and Polynesian origins. Journal of the Polynesian Society 80: 278-316.

Hōjō, Y. and K. Yoshida. 2007. Dōitai bunseki kekka kara mita senshi jidaijin to kinsei Amitorijin. In Tōkai University (eds), Amitori iseki, Katura kaizuka no kenkyū, pp. 263-268. Hiratsuka: Tōkai University.

Hudson, M.J. 1994. The linguistic prehistory of Japan: Some archaeological speculations. Anthropological Science 102: 231-255. doi.org/10.1537/ase.102.231.

—. 1999. Ruins of Identity: Ethnogenesis in the Japanese Islands. Honolulu: University of Hawaii Press. 
Hung, H.-c., M.T. Carson, P. Bellwood, F.Z. Campos, P.J. Piper, E. Dizon, M.J.L.A. Bolunia, M. Oxenham and Z. Chi. 2011. The first settlement of Remote Oceania: The Philippines to the Marianas. Antiquity 85: 909-926. doi.org/10.1017/S0003598X00068393.

Hung, H.-c. and Carson, M.T. 2014. Foragers, fishers and farmers: Origins of the Taiwanese Neolithic. Antiquity 88: 1115-1131. doi.org/10.1017/S0003598X00115352.

Kin, M. 1994. Doki $\rightarrow$ mudoki $\rightarrow$ doki: Yaeyama kōko hennen shian. Nantō Kōko 14: 83-92.

Kirch, P.V. 1985. Feathered Gods and Fishhooks: An Introduction to Hawaiian Archaeology and Prehistory. Honolulu: University of Hawaii Press.

Li, K.-T. 2001. Prehistoric marine fishing adaptation in southern Taiwan. Journal of East Asian Archaeology 3(1-2): 47-74.

Lu, J.-C. 2012. The Neolithic cultures in southern Ryukyu and eastern coast of Taiwan. Paper presented at the Fifth World Conference of the Society for East Asian Archaeology, Fukuoka, June 2012.

Matthews, P.J., E. Takei and T. Kawahara. 1992. Colocasia esculenta var. aquatilis on Okinawa island, southern Japan: The distribution and possible origins of a wild diploid taro. Man \& Culture in Oceania 8: 19-34.

Miyagi, H. (ed.). 2012. Sakishima chi’iki ni okeru senshi jidai no shūen to suku iseki shutsugen ni kansuru kenky $\bar{u}$ [Research on the end of prehistory and the appearance of Suku sites in the Sakishima region]. Mitsubishi Foundation Grant Report for the Humanities no. 31.

Nagabaka Archaeological Research Project (eds). 2013. Pai-mmi-nu-Nagabaka iseki chōsa kenkyū 1. Kanzaki: University of West Kyushu.

Najima, Y. 2013. Nagabaka iseki shutsudo no gyorui itai (2008 nendo chōsa shutsudo shiryō) [Fish remains excavated from the Nagabaka site (Materials from the 2008 season)]. In Nagabaka Archaeological Research Project (eds), Pai-mmi-nu-Nagabaka iseki chōsa kenkyū 1 [Pai-mmi-nuNagabaka, vol. 1], pp. 83-105. Kanzaki: University of West Kyushu.

Oda, S. 1981. The archaeology of the Ogasawara islands. Asian Perspectives 14: 111-138.

1990. A review of archaeological research in the Izu and Ogasawara Islands. Man \& Culture in Oceania 6: 53-79.

Ōhama, E. 1999. Yaeyama no kōkogaku. Ishigaki: Sakishima Bunka Kenkyūjo.

Oppenheimer, S. and M. Richards. 2002. Polynesians: Devolved Taiwanese rice farmers or Wallacean maritime traders with fishing, foraging and horticultural skills? In P. Bellwood and C. Renfrew (eds), Examining the Farming/Language Dispersal Hypothesis, pp. 287-297. Cambridge: McDonald Institute.

Pawlik, A.F., P.J. Piper, R. Wood, K.A.A. Lim, M.G.P.G. Faylona, A.S.B. Mijares, A.S.B. and M. Porr. 2015. The direct dating and analysis of an early middle Holocene shell adze from Ilin Island, Mindoro, Philippines and its implications for understanding shell tool technology in Island Southeast Asia. Antiquity 89(344): 292-308. doi.org/10.15184/aqy.2015.3.

Pearson, R.J. 1969. Archaeology of the Ryukyu Islands. Honolulu: University of Hawaii Press.

—. 2013. Ancient Ryukyu: An Archaeological Study of Island Communities. Honolulu: University of Hawai'i Press.

Pellard, T. 2015. The linguistic archaeology of the Ryūkyū Islands. In P. Heinrich, S. Miyara and M. Shimoji (eds), Handbook of the Ryukyuan Languages. pp. 13-37. Amsterdam: DeGruyter Mouton. 
Pietrusewsky, M. 2010. A multivariate analysis of measurements recorded in early and more modern crania from East Asia and Southeast Asia. Quaternary International 211: 42-54. doi.org/10.1016/j. quaint.2008.12.011.

Rauzon, M.J. 2001. Isles of Refuge: Wildlife and History of the Northwestern Hawaiian Islands. Honolulu: University of Hawai'i Press.

Ronquillo, W.P. 1998. Tools from the sea. In G.S. Casal, E.Z. Dizon, W.P. Ronquillo and C.G. Salcedo, Kasaysayan: The Story of the Filipino People Vol. 2: The Earliest Filipinos, pp. 63-75. Manila: Asia Publishing.

Russell, S. 1998. Gani revisited: A historical overview of the Mariana archipelago's northern islands. Pacific Studies 21(4): 83-105.

Shimabukuro, A. 2011. Sakishima shotō no senshijidai. In H. Takamiya and S. Itō (eds), Senshi, genshi jidai no Ryūkyū rettō: hito to keikan [The prehistoric and protohistoric Ryukyu islands: People and landscapes], pp. 267-289. Tokyo: Rokuichi Shobō.

Solheim, W.G. 1975. The Nusantao and South China. Journal of the Hong Kong Archaeological Society 6: 108-115.

- 2007. Archaeology and Culture in Southeast Asia: Unraveling the Nusantao. Honolulu: University of Hawai'i Press.

Summerhayes, G.R. and A. Anderson. 2009. An Austronesian presence in southern Japan: Early occupation in the Yaeyama Islands. Bulletin of the Indo-Pacific Prehistory Association 29: 76-91. doi. org/10.7152/bippa.v29i0.9481.

Takamiya, H. 2003. Arafu iseki shutsudo no shokubutsu itai [Plant remains from the Arafu site]. In T. Egami (ed.), Arafu iseki chōsa kenkyū I vol. 1, pp. 105-106. Tokyo: Rokuichi Shobō.

- 2004. Population dynamics in the prehistory of Okinawa. In S.M. Fitzpatrick (ed.), Voyages of Discovery: The Archaeology of Islands, pp. 111-128. Westport, CT: Praeger.

Takamiya, H., M.J. Hudson, H. Yonenobu, T. Kurozumi and T. Toizumi. 2016. An extraordinary case in human history: Prehistoric hunter-gatherer adaptation to the islands of the Central Ryukyus (Amami and Okinawa arhipelagos), Japan. The Holocene 26: 408-422. doi. org/10.1177/0959683615609752.

Takemoto, M. 2003. Jōmon jidai [Jōmon period]. In Okinawa Prefecture (eds), Okinawakenshi kakuronhen 2: kōko, pp. 97-182. Naha: Okinawa Prefecture Board of Education.

Tokyo Board of Education. 2005. Kitaiojima Ishino iseki. Tokyo: Tokyo Board of Education.

Yamamoto, M. 2008. The Gusuku period in the Okinawa islands. Acta Asiatica 95: 1-17. 
This text is taken from New Perspectives in Southeast Asian and Pacific Prehistory, edited by Philip J. Piper, Hirofumi Matsumura and David Bulbeck, published 2017 by ANU Press, The Australian National University, Canberra, Australia. 